Dept. of Anatomy and Histology,

Faculty of Vet. Med., Assiut University, Assiut, Egypt.

\title{
COMPARATIVE MORPHOLOGICAL FEATURES OF THE PLACENTAL BARRIER AND LOCALIZATION OF ESTROGEN RECEPTORS $\alpha$ IN THE PLACENTA OF COWS AND BUFFALOES
}

(With 6 Figures)

\author{
By \\ M.M.M. ABD-ELNAEIM
}

(Received at 13/3/2007)

دراسة موففولوجية مقارنة لخصائص الحاجز المشبيمى وكنلتك مستقبلات

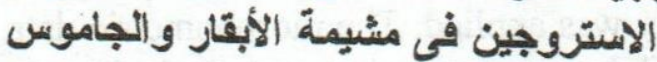

\section{محمود معد محمور عبل زلنعيم}

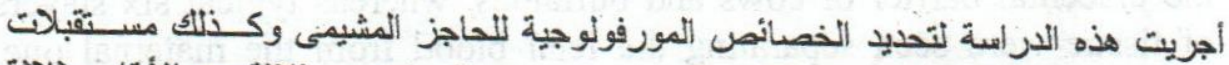

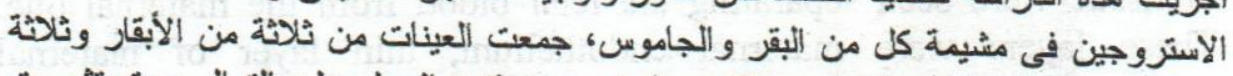

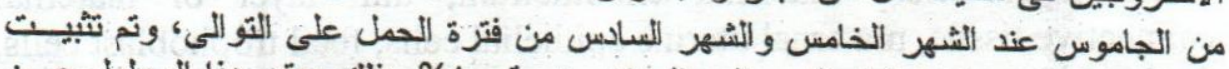

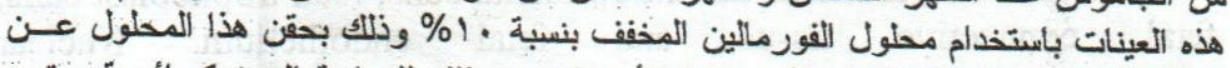

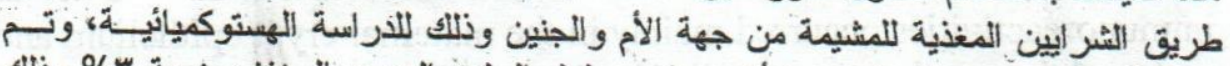

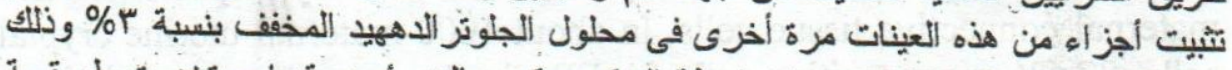

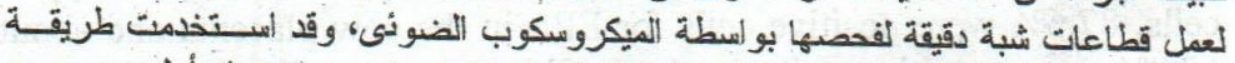

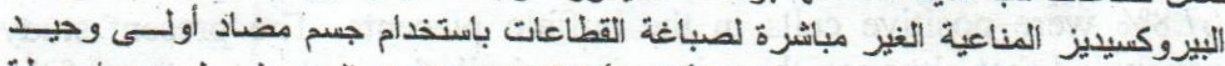

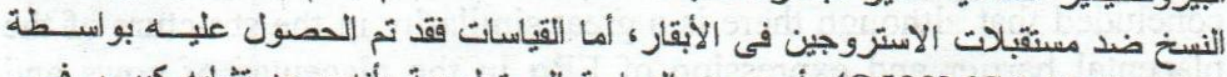

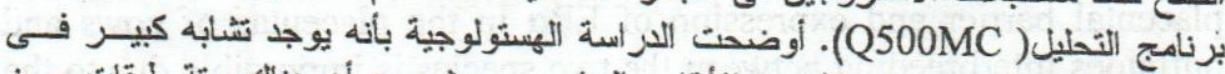

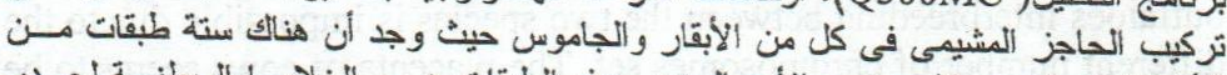

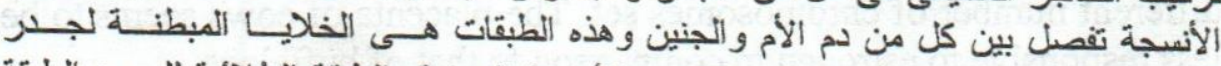

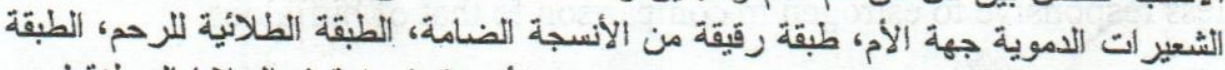

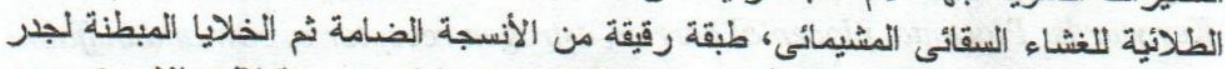

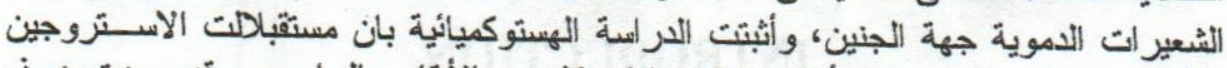

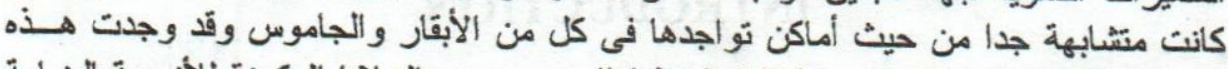

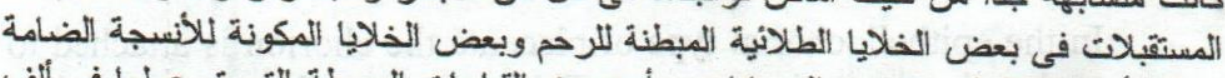

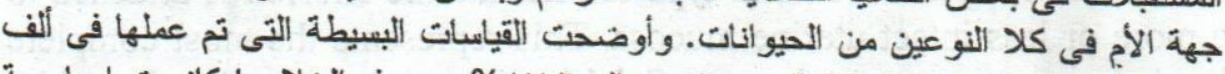

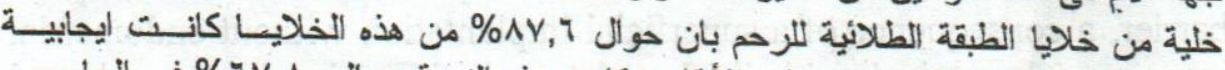

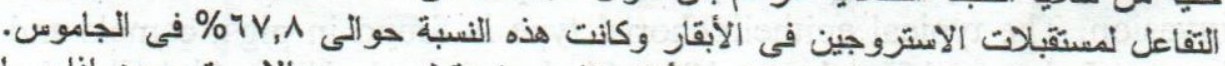

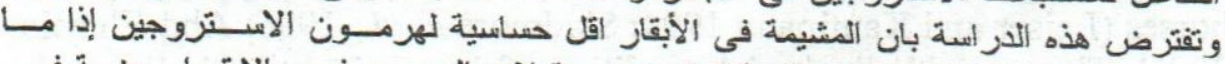

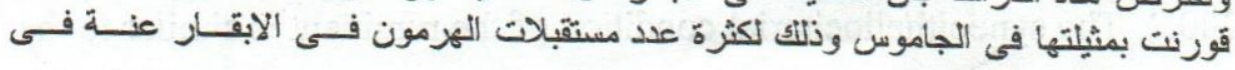




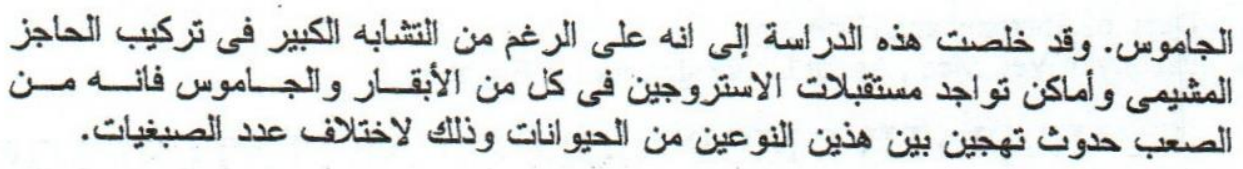

\section{SUMMARY}

The present study was conducted to identify the morphological characteristics of the placental barrier and localization of estrogen receptors $\alpha$ in the cow and buffalo placentas. Placentomes were collected from 3 pregnant cows and 3 pregnant buffaloes at the $5^{\text {th }}$ and $6^{\text {th }}$ months of gestation respectively. The placentomes were fixed by using $10 \%$ neutral buffered formalin for immunohistochimestry and were post fixed in $3 \%$ glutaraldehyde for light microscopy. Indirect immunoperoxidase staining methods using monoclonal antibody against bovine $\mathrm{ER} \alpha$ as primary antibody was applied. The morphometric data were obtained by using Q500 MC Image processing and analysis program. Histological examination revealed that there is a great similarity in the structure of the placental barrier of cows and buffaloes, whereas typical six slayers of tissue were seen separating the fetal blood from the maternal one. These layers were maternal endothelium, thin layer of maternal connective tissue, maternal uterine epithelial cells, fetal trophoblast cells, fetal connective tissue and fetal endothelium. Nuclear immunoreactivities occurred mainly in the maternal crypt epithelium and maternal connective tissue cells. In about 1000 maternal uterine cryptal cells, $87.6 \%$ were positive cells for $\mathrm{ER} \alpha$ in the cow placenta and about $67.8 \%$ were positive cells in the buffalo placenta. The present study concluded that although there is a great similarity in the structure of the placental barrier and expression of ER $\alpha$ in the placentas of cows and buffaloes interbreeding between the two species is impossible due to the different number of chromosomes set. The placenta of cows seems to be less responsive to estrogen in comparison to that of buffaloes.

Key words: Placenta, placental barrier, estrogen receptor $\alpha$, cow and buffalo.

\section{INTRODUCTION}

In the epitheliochorial type of placenta the chorion is attached to a more or less intact uterine mucosa. This represents the most complete barrier, a consequence of a superficial implantation without endometrial invasion. The typical epitheliochorial type is found in pigs, camels and horses (Leiser and Kaufmann 1994; Skidmore et al., 1996; Abd-Elnaeim 2003). The synepitheliochorial condition of the ruminant is similar to the 
epitheliochorial type (Wooding and Flint 1994; Wooding et al., 1997) however; some binucleate or giant trophoblast cells fuse with the uterine epithelial cells forming hybrid symplasms (Wooding 1992; Wooding and Flint 1994; Guillomot 1995; Wooding et al., 1997; Klisch et al., 1999). The syndesmochorial condition obviously does not persist as a placental type among mammals but rather is a transitory stage on the way to the endotheliochorial condition (Wooding 1992; Leiser and Kaufmann 1994).

The functional significance of the fusion of the binucleate cells with the maternal uterine epithelial cells is thought to be the transport of fetal substances across the placental barrier and their release into the maternal side (Wooding 1982; Wooding and Flint 1994). These cells are concerned with the production of steroids and metabolism of prostaglandin (Reimers et al. 1985; Gross and Williams 1988; Wodding et al., 1997).

Estrogens are key molecules in development, differentiation, and growth, whose actions are mediated by specific cellular receptor proteins localized in the nucleus of the target cell (Gorski 1986; Evans 1988; Riberio et al., 1995). In cattle the placenta produces large amount of steroids, mainly estrogens and sites of estrogen production are the fetal cotyledons (Hoffmann et al., 1979; Schuler et al., 1994). The main estrogen secreted is estrone, predominantly in its sulfoconjugated form (Hoffmann et al., 1997). In cattle, placental estrogens started to be produced from the first trimester until the end of its life span and estrogen receptor $\alpha$ was identified in the maternal caruncular epithelium, maternal stromal cells and capillary pericytes of the maternal caruncular septa (Schuler et al., 2002).

The present study was conducted to identify the morphological characteristics of the placental barrier and localization of estrogen receptors $\alpha$ in the cow and buffalo placentomes by using light microscopy and immunohistochimestry. This was performed to test for the degree of structural and functional similarity of the placenta in both species.

\section{MATERIALS and METHODS}

\section{Tissue collection and embedding}

Placentomes were collected from three cows and three buffalos that were pregnant for 5 and 6 months respectively. Samples were obtained directly after slaughtering by opening the uterus and removing the fetus, cotyledonary arteries of up to eight placentomes from the mid- 
region of the pregnant horn were canulated, and cotyledons were perfused with $10 \%$ neutral phosphate-buffered formalin as a fixative. This area that contained the eight placentomes was dissected from the uterus and perfusion fixation with the same fixative was performed through branches of the uterine arteries that supply for fixation of the corresponding maternal caruncles. From all placentomes small wedgeshaped pieces encompassing the total height of the placentome were processed routinely for light microscopy and embedded in paraffin for immunohistochimestry. Small pieces from the formalin-fixed tissues were post fixed in $3 \%(\mathrm{v} / \mathrm{v})$ glutaraldehyde in $0.1 \mathrm{M}$ phosphate buffer $\mathrm{pH} 7.3$ (Björkman et al., 1981). After osmication in $1 \% \mathrm{OsO}_{4}(\mathrm{w} / \mathrm{v})$ in $0.1 \mathrm{M}$ phosphate buffer $\mathrm{pH} 7.3$ for $2 \mathrm{~h}$ at room temperature the specimens were washed in the same buffer, then dehydrated in a graded series of ethanol and embedded in Araldite 502 (Luft, 1961). Semithin sections $(1 \mu \mathrm{m}$ thick) were cut using a Reichert Ultracut microtome (Leica) and stained with toluidine blue. The sections were examined and photographed by using a Zeiss Axiophot microscope.

\section{Immunocytochemistry}

Indirect immunoperoxidase staining methods using murine monoclonal antibody (mabs) against bovine ER $\alpha$ (clone AER311; Neomarkers/Dunn Labortechnik, D-53367 Asbach) as primary antibody was applied. Blocking sera, biotinylated secondary antibody and avidinbiotin complex were taken from Vectastain Elite ABC Kit 6102 for the detection mouse IgG and used following the producer's instructions (Vector Laboratories, Laboratories, Burlingame, CA 94010, USA).

About $4 \mu \mathrm{m}$ tissue sections were mounted on SuperFrost-Plus slides (Menzel Glaeser, D-38116 Braunschweig), deparaffinized by two 5 min changes of xylene, rehydrated in graded ethanol and washed under running tap water $(5 \mathrm{~min})$. For antigen retrieval the rehydrated sections were preincubated in $10 \mathrm{mM}$ citrate buffer $\mathrm{pH} 6.0$ for 5 min prior to three times $5 \mathrm{~min}$ microwave irradiation in pre-heated citrate buffer in an oven run at $560 \mathrm{~W}$. After a 20 min cooling period the slides were washed under running tap water for $5 \mathrm{~min}$ followed by a treatment with $0.3 \%$ hydrogen peroxide in methanol for $30 \mathrm{~min}$ in order to quench endogenous peroxidase activity. They were then washed with PBS (phosphate buffer saline) $\mathrm{pH} 7.2$ for $5 \mathrm{~min}$, covered with $10 \%$ inactivated blocking serum in PBS pH 7.2 to block unspecific binding sites. After draining the blocking reagent, the respective primary antibody diluted in PBS pH 7.2 (1:100) was applied and the slides were incubated for $20 \mathrm{~h}$ in a humid chamber at $4^{\circ} \mathrm{C}$. They were then washed 
with PBS pH 7.2, covered with biotinylated secondary antibody diluted in PBS pH 7.2 and incubated for $30 \mathrm{~min}$ at room temperature. Following draining of excess antibody, the sections were washed for 5 min with PBS pH 7.2, then covered with streptavidin-peroxidase complex and incubated for $30 \mathrm{~min}$. After washing with PBS pH 7.2 (5 min) the sections were incubated with substrate (AEC substrate kit for peroxidase, Vector, Laboratories, Burlingame, CA 94010, USA). The slides were washed under running tap water for $5 \mathrm{~min}$, counterstained with hematoxylin and mounted in Kaisers glycerol gelatine (Merck KgaA, D-64293 Darmstadt). Negative controls were set up replacing the respective primary antibodies with incubation buffer.

\section{Evaluation of immunostaining}

For quantitative assessment of ER $\alpha$-positive cryptal cells three sections of a randomly chosen placentomes per cow and buffalo were analyzed. Sections from the middle part of the placentomes were used. The total number of maternal cryptal cells and the number of ER $\alpha$ positive cryptal cells were counted at 400 -fold magnification and the percentage of ER-positive cryptal cells was calculated. These morphometric data were obtained by using Q500 MC Image processing and analysis program (Leica).

\section{RESULTS}

Histological examination of semithin sections revealed that there is a great similarity in the structure of the placental interhaemal barrier of cows and buffaloes. This means typical six slayers of tissue components were seen separating the fetal blood from the maternal one. These layers were maternal endothelium, thin layer of maternal connective tissue, maternal uterine epithelial cells, fetal trophoblast cells, fetal connective tissue and fetal endothelium (Figs. 1, 2). The thickness of the placental barrier was greatly variable from one place to another in both cows and buffalos, depending on thinning of the maternal uterine epithelium, great reduction in the thickness of the connective tissue layer that interposed between the maternal endothelium and maternal epithelium as well as between the fetal endothelium and fetal trophoblast cells. This was in addition to great indentation of the fetal trophoblast cells with the fetal capillaries. Binucleat cells of variable diameters were commonly seen in the placenta of both species (Figs. 1,2).

Nuclear staining was the prominent feature of immunohistochimestry using AER 311 antibody in the buffalo and cow placentomes (Figs. 3,4). Nuclear immunoreactivities occurred mainly in 
the maternal crypt epithelium and maternal connective tissue cells (Figs. 5, 6). Positive cytoplasmic reactions were not observed either in the fetal or maternal placental tissues in both species. In about 1000 maternal uterine cryptal cells $87.6 \%$ were positive and $12.4 \%$ were negative cells in the cow placenta. However, about $67.8 \%$ were positive cells and $32.2 \%$ were negative cells in the buffalo placenta.

\section{LEGENDS}

Fig. 1: Light micrograph showing the arrangement of the placental barrier in the cow placenta. It consists typically of walls of the flattened maternal capillaries (arrowheads), thin layer of maternal connective tissues, maternal epithelium (ME) of variable thickness, fetal epithelium (FE) which is greatly indent by fetal capillaries, fetal connective tissues and the walls of fetal blood capillaries. X 400.

Fig. 2: Light micrograph showing the arrangement of the placental barrier in the buffalo placenta. This barrier consists of typical six layers like that of the cow, endothelium of maternal capillaries (arrowheads), thin connective tissue layer, maternal epithelium (ME), fetal epithelium (FE), fetal connective tissue layer and fetal endothelium. X 400.

Fig. 3: Immunohistochemical reaction of estrogen receptors $\alpha$ in the cow placenta showing an overview of the positively reacted maternal placental tissues (MT) and negatively reacted fetal placental tissues (FT).

Fig. 4: Immunohistochemical reaction of estrogen receptors $\alpha$ in the buffalo placenta showing strong positive signals in the maternal placental tissues (MT) and negative reactions in the fetal ones (FT).

Fig. 5: Higher magnifications from the cow placenta demonstrating strong positive immunohistochemical reactions in the maternal cryptal epithelium (arrows) and maternal mesenchyme (arrowheads). Fetal epithelium (FE), fetal mesenchyme (FM) and fetal blood capillaries (FC) are negatively reacted.

Fig. 6: Higher magnifications from the buffalo placenta illustrating strong positive immunohistochemical signals for estrogen receptor $\alpha$ in the maternal cryptal epithelium (arrows) and maternal mesenchyme (arrowheads). Fetal epithelium (FE), fetal mesenchyme (FM) and fetal blood capillaries (FC) are negatively reacted. 


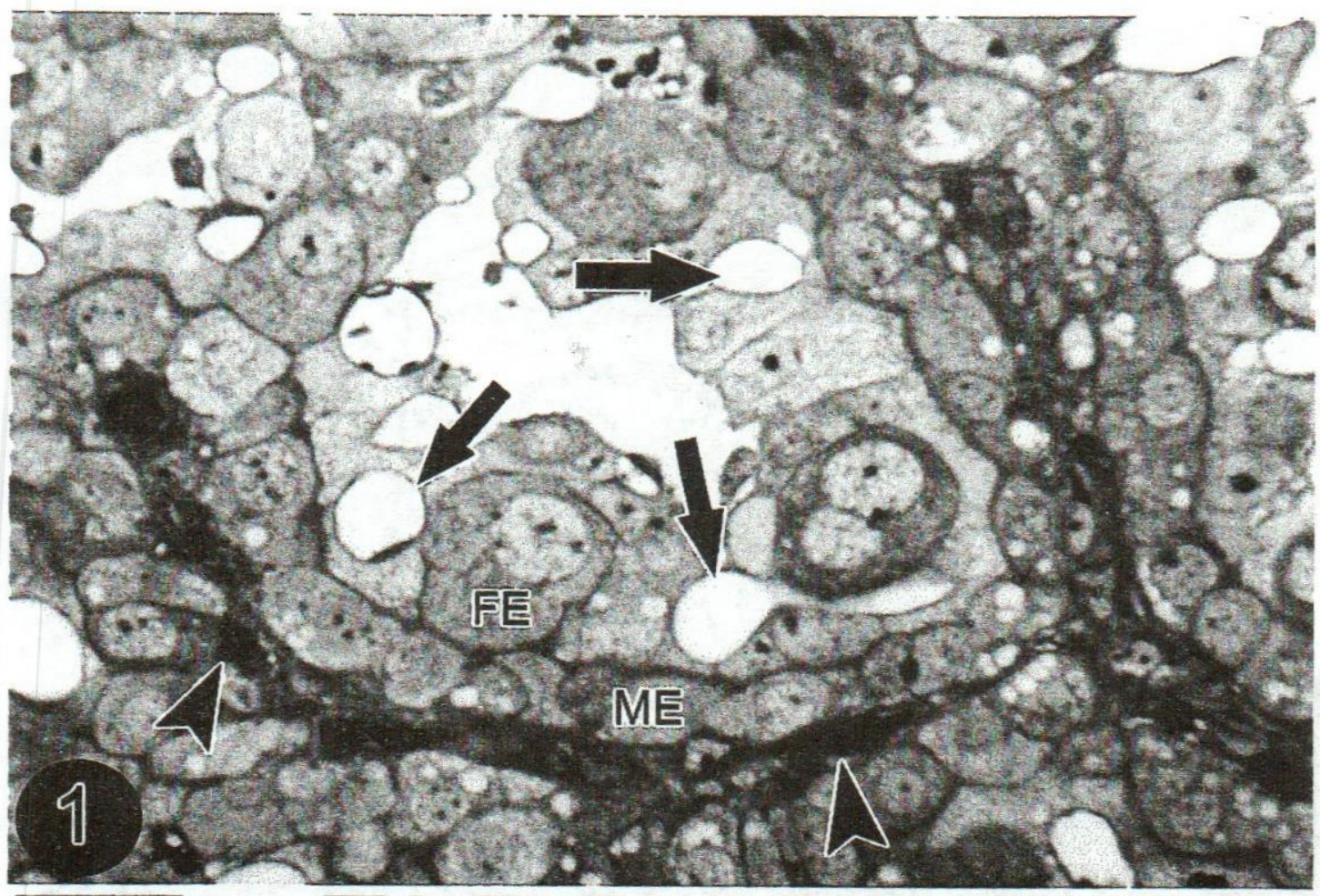

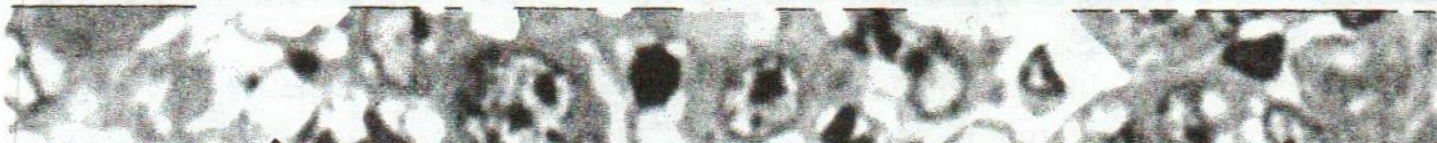

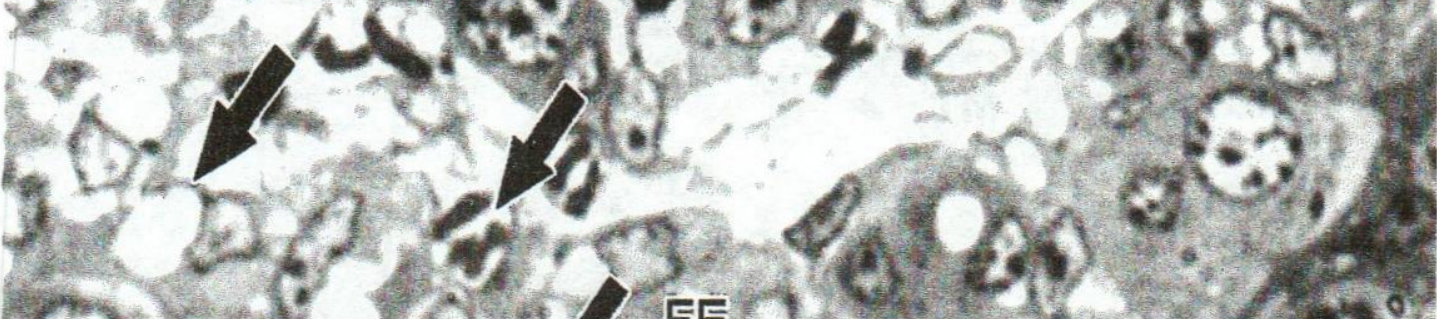

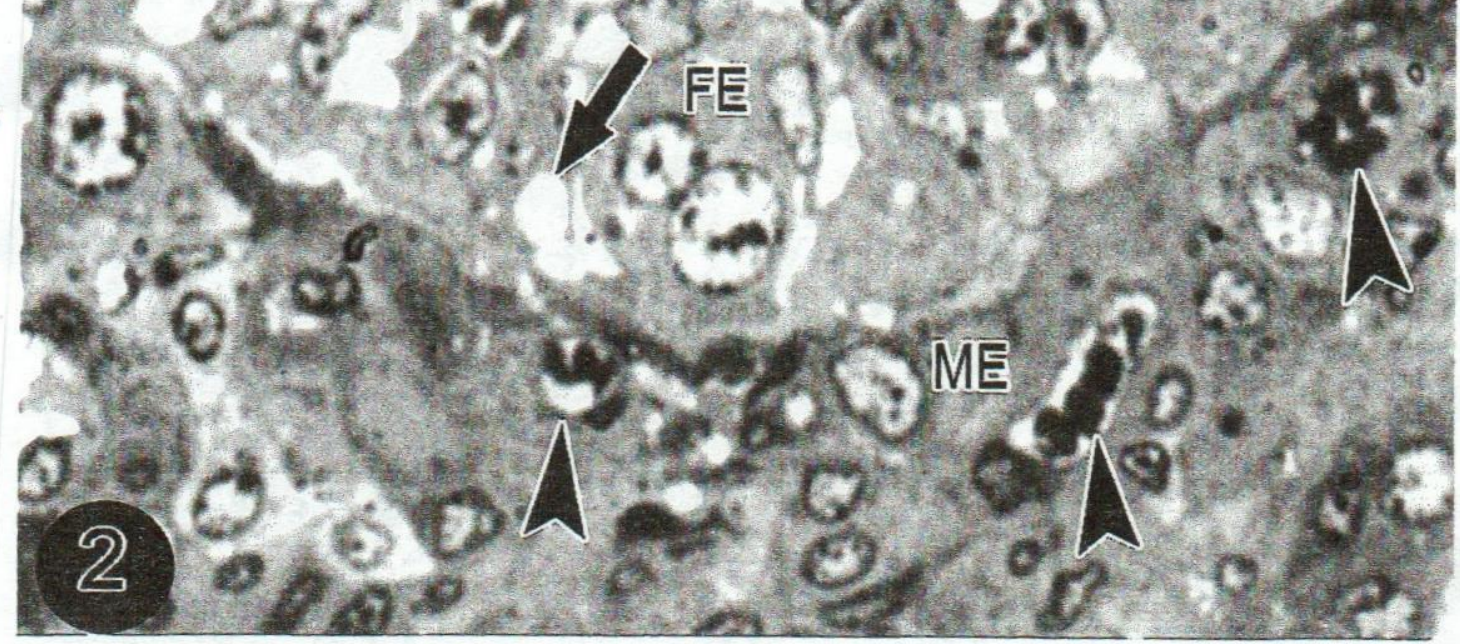




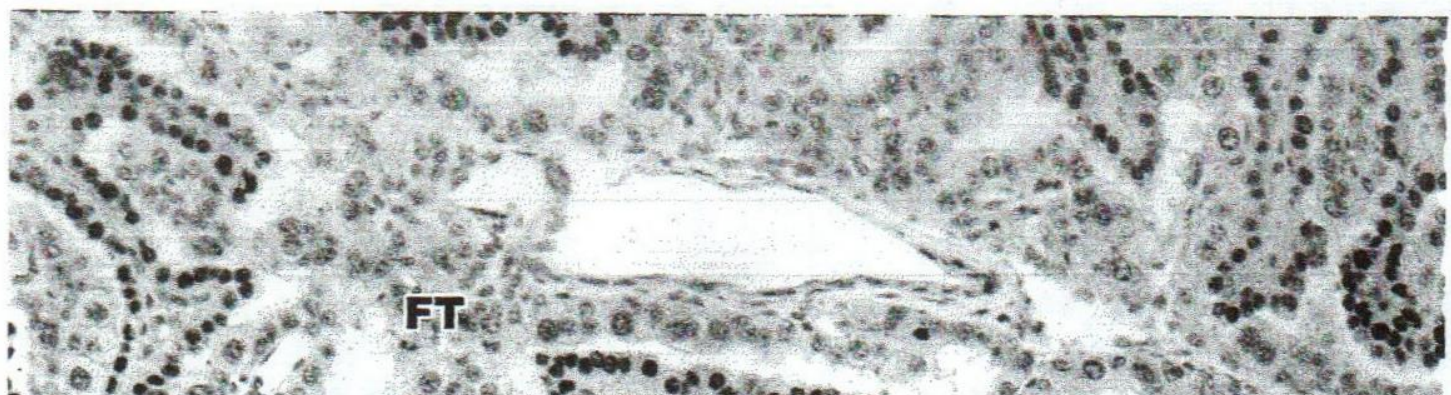

$\because \% 2$ at $5=$

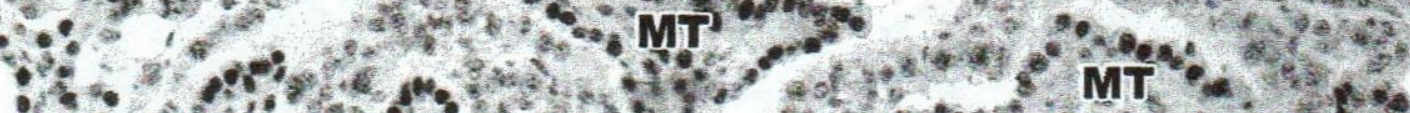

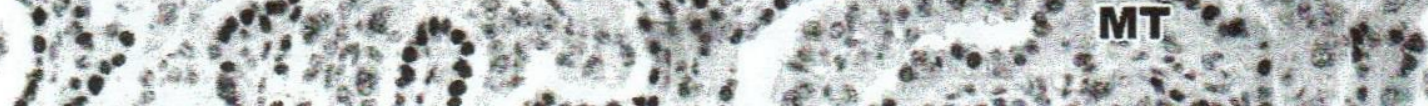

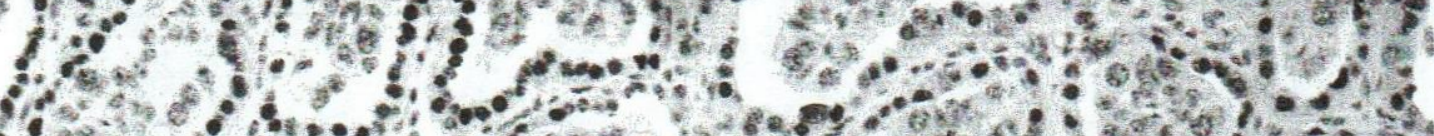

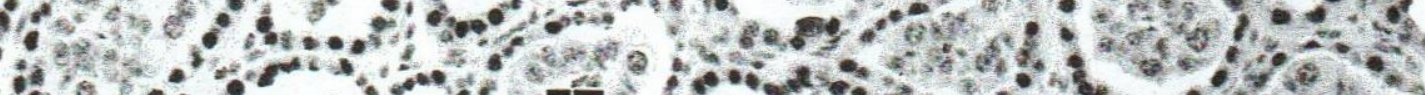

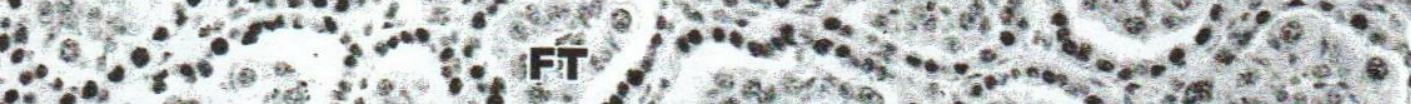

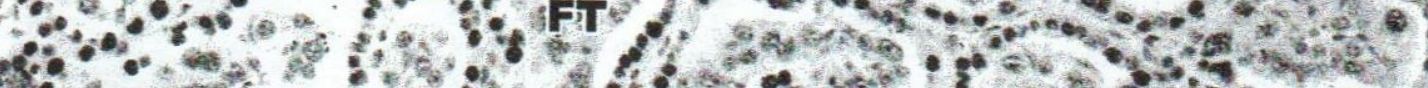

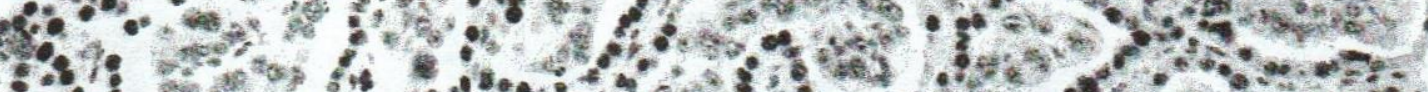

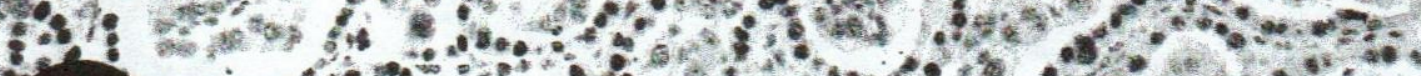

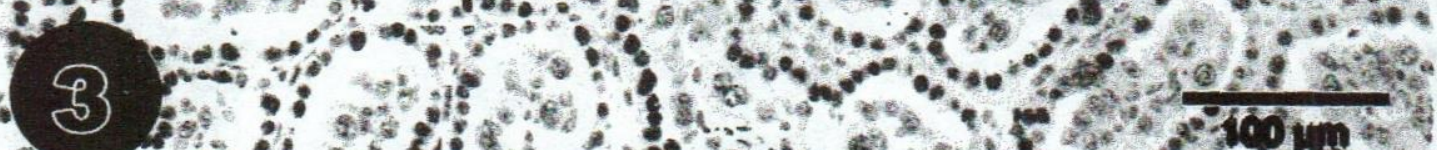

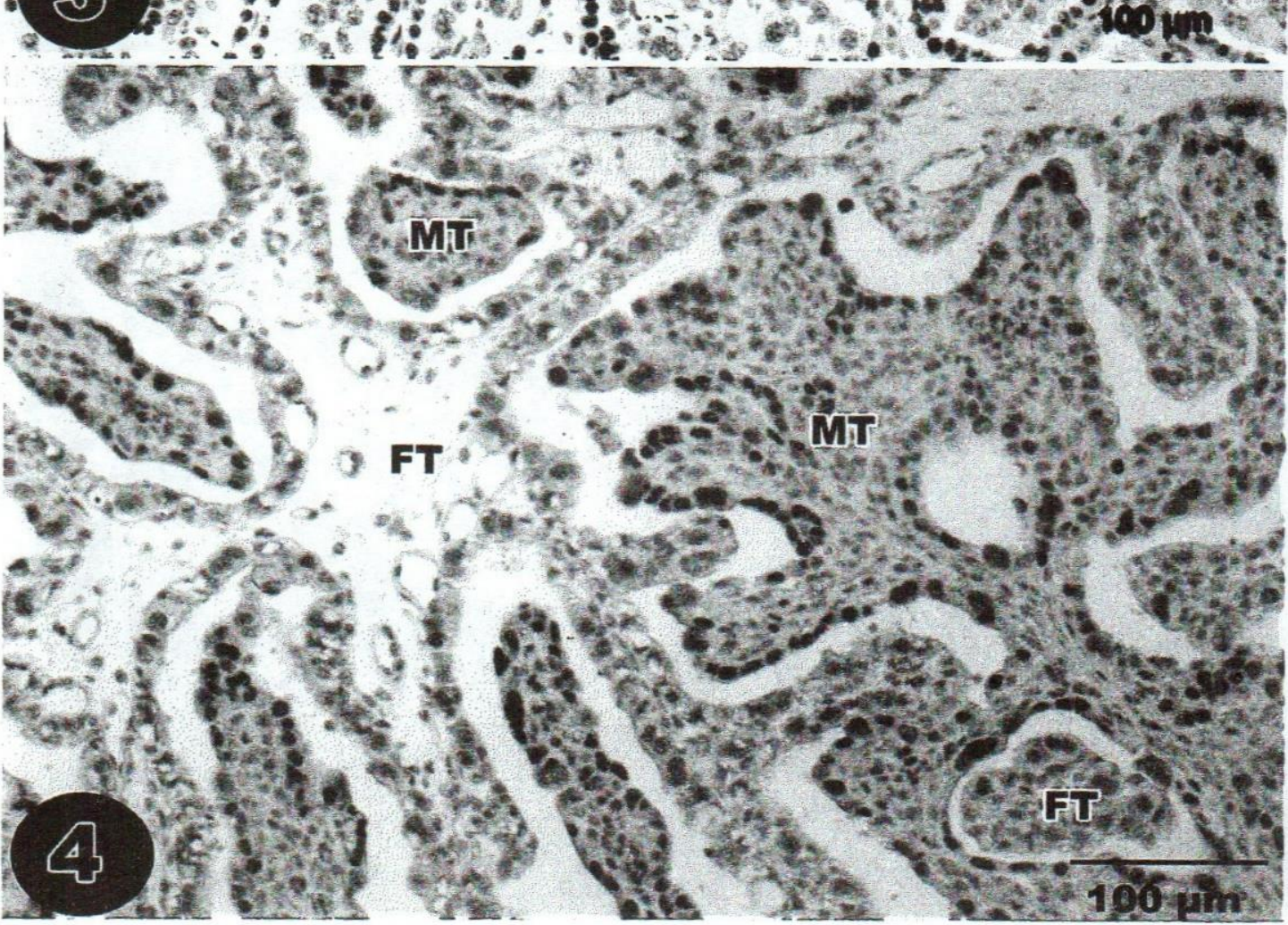



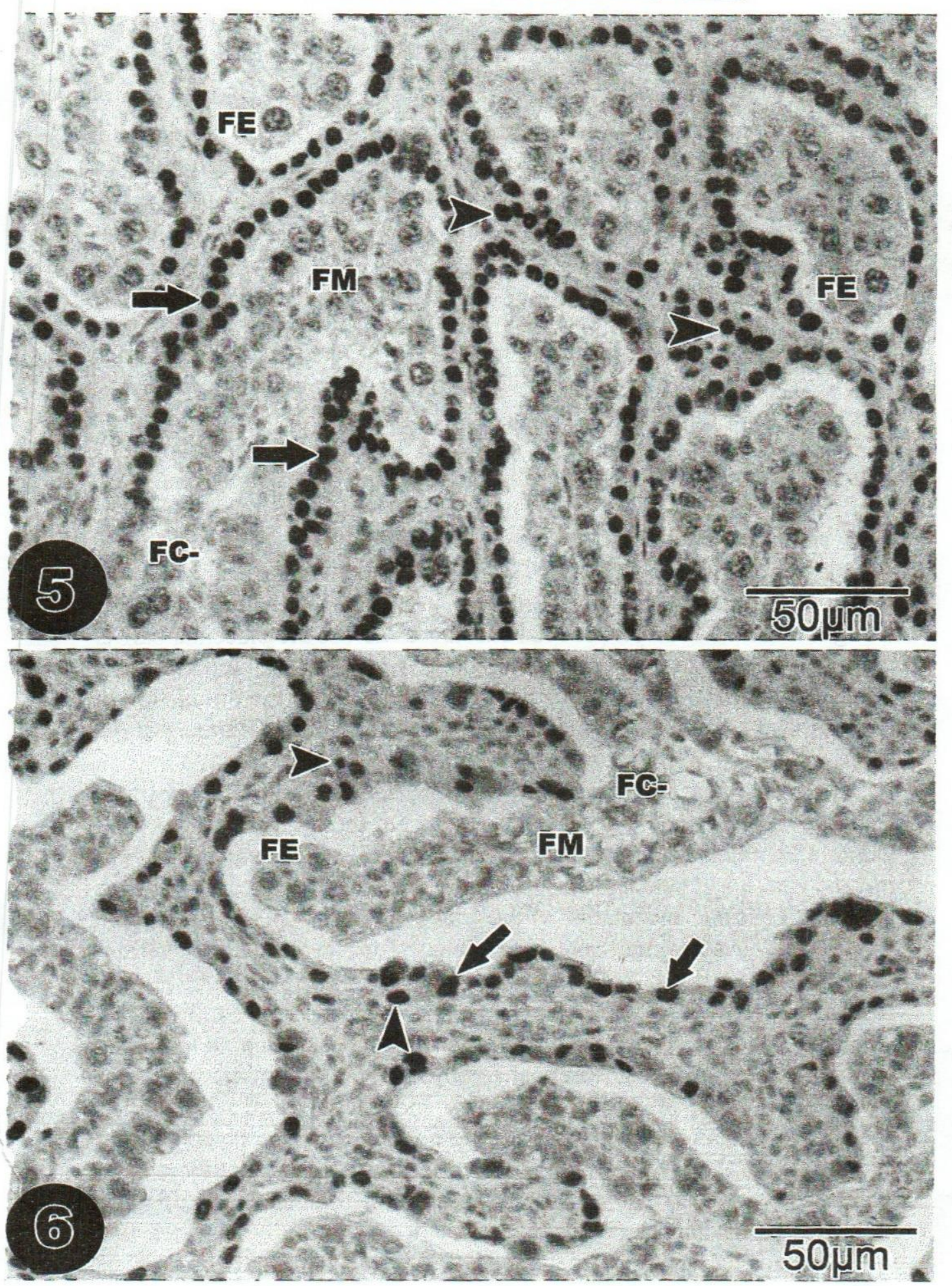


\section{DISCUSSION}

The present study revealed that there is a great similarity in the structure of the placental barrier in cows and buffaloes. In both species six layers were found to separate the fetal blood from the maternal one. This type of barrier named complete one because there were no invasive trophoblast cells in both species. It was believable for a long time that the placental barrier in ruminants is syndesmochorial. This condition obviously does not persist as a placental type among mammals but rather is a transitory stage on the way to the endotheliochorial condition (Wooding 1992; Leiser and Kaufmann 1994). The most common and usable name of the placental barrier in ruminants is synepitheliochorial; this name was introduced by Wooding (1992) and Wooding and Flint (1994). The synepitheliochorial condition (Guillomot 1995; Wooding et al., 1997) is similar to the epitheliochorial type; however, some trophoblast (binucleate or giant) cells were found to migrate from the fetal side and fuse with the uterine epithelial cells forming hybrid symplasms (Klisch et al., 1999). The functional significance of the fusion of the binucleate cells with the maternal uterine epithelial cells is thought to be the transport of fetal substances across the placental barrier and their release into the maternal side (Wooding 1982; Wooding and Flint 1994). These binucleate cells are concerned with the production of steroids like estrogens and metabolism of prostaglandin (Reimers et al., 1985; Gross and Williams 1988; Wodding et al., 1997).

It was clear in the present study that the fetal blood is separated from the maternal one by typical six layers but these layers were greatly variable in thickness from one place to another. The variability was mainly due to decrement in the thickness of the maternal uterine epithelial cells and indentation of the fetal trophoblast cells with the fetal capillaries. These events have been recorded in several animal species like pigs (Dantzer 1985), camels (Abd-Elnaeim et al., 1999) and equines (Abd-Elnaeim et al., 2006). Therefore, the present study confirms that the placenta of cows and buffalos is typical epitheliochorial (synepitheliochorial). Theoretically, this type of placentae was considered to be of lower efficiency and more primitive than its haemochorial counterpart. However, the number of tissue layers present may influence the mechanisms by which transport occurs but there is no evidence to suggest that it has any bearing on the efficiency of these processes (Kaufmann and Burton 1994). It can be easily assumed that with decreasing number of tissue layers transplacental transfer is 
facilitated and that the epitheliochorial placenta of the pig must be less effective than the haemochorial placenta of the human. However, phsiological studies (Faber and Thornburg 1983; Thorburn and Harding 1994) have shown that this is wrong because a simple evaluation of birth weights is able to illustrate this misinterpretation. One gram of the epitheliochorial placenta of the pig is sufficient to supply 9 grams of the fetus at term and for the more sophisticated haemochorial human placenta; this ratio is only 6:1 (Dantzer et al., 1988).

According to the immunohistochemical results of the present study expression of $E R \alpha$ is restricted to the maternal part of the placenta, caruncular epithelium and stroma, in both cows and buffaloes. This is similar to the finding of Schuler et al. (2002) in the cow. However, positive nuclear reactions were also detected in the tunica media of fetal blood vessels of the cow placenta by Boos et al. (2000). The latter authors reported that occasionally a diffuse; weak to moderate cytoplasmic signals were observed in the trophoblast cells, which was not present in the negative control. They regarded these signals unspecific because this cytoplasmic staining was not accompanied by nuclear signals. Identification of ER $\alpha$ in the caruncular stromal and epithelial cells suggests that they are target cells of estrogens produced in the trophoblast cells and points to a role of placental estrogens as paracrine regulators of caruncular growth and differentiation (Schuler et al., 2002). This hypothesis is supported by the fact that proliferative activity of the ER $\alpha$-expressing caruncular stromal follows local estrogen tissue concentrations in the second half of gestation (Tsumagari et al., 1993; Schuler et al., 1999).

In the present study the number of ER $\alpha$-positive caruncular epithelial cells was considerably higher in the cow placenta in comparison to that of buffaloes. Therefore, this may suggests that the buffalo placentomes are more responsive to estrogens than the cow placentomes. The production and secretion of estrogens in normal pregnancy are known to rise continuously throughout pregnancy (Loriaux et al., 1972). Therefore, the placental estrogen level is high at time of parturition in the cow (Schuler et al., 2002) but the number of ER $\alpha$-positive caruncular cells was considerably reduced (Sauerwein et al., 1989). This may indicate that a mature placenta with no or only marginal functions in respect to placental release (Schuler et al., 2002). The present study concluded that although the great similarity in the structure of the placental barrier and expression of ER $\alpha$ in the placentae of cows and buffaloes, interbreeding between the two species is 
impossible due to the different number of chromosomes set (cow 60 and buffalo 48 ).

\section{REFERENCES}

Abd-Elnaeim, M.M.M. (2003): Microvascular architecture of the mare placenta at mid-gestation: a light and scanning electron microscopical study. Assiut Vet. Med. J., Vol. 96, No. 49, 1-25. Abd-Elnaeim, M.M.M.; Pfarrer, C.; Saber, A.S.; Abou El-Magd, A.; Jones, C.J.P. and Leiser, R. (1999): Feto-maternal attachment and anchorage in the early diffuse epitheliochorial placenta of the camel (Camelus dromedarius): Light-, transmission and scanning electron microscope study. Cells Tissues Organs 164: 141-154.

Abd-Elnaeim, M.M.M.; Leiser, R.; Sandra Wilsher and Allen, W.R. (2006): Structural and haemovascular aspects of placentation in young and aged mares. Placenta, 27: 1103-1113.

Björkman, N.; Dantzer, V.; Hasselager, E.; Holm, H. and Kjaersgaard, $P$. (1981): Perfusion in vivo of the porcine placenta: fixation for EM. Placenta 2: 287-302.

Boos, A.; Kohtes, J.; Stelljes, A.; Zerbe, H. and Thole, H.H. (2000): Immunohistochemical assessment of progesterone, oestrogen and glucocorticoid receptors in the bovine placentomes during pregnancy, induced parturition, and after birth with or without retention of fetal membranes. J. Reprod. Fertile. 120: 351-360.

Dantzer, V. (1985): Electron microscopy of the initial stages of placentation in the pig. Anat. Embryol. 172: 281-293.

Dantzer, V.; Leiser, R.; Kaufmann, P. and Lukhardt, M. (1988): Comparative morphological aspects of placental vascularization. Trophoblast Res. 3: 235-260.

Evans, R.M. (1988): The steroid and thyroid hormone receptor superfamily. Science 240: 889-895.

Faber, J.J.; Thornburg, K.L. (1983): Placental physiology. Structure and function of fetomaternal exchange. New York, Raven, pp1-191.

Gorski, J. (1986): The nature and development of steroid hormone receptors. Experiential 41: 744-750.

Gross, T.S. and Williams, W.F. (1988): Bovine placental prostaglandine synthesis: principal cell synthesis as modulated by the binucleate cell. Biol. Reprod. 38: 1027-1034. 
Guillomot, M. (1995): Cellular interaction during implantation in domestic ruminants. J. Reprod. Fertil. Suppl. 49:39-51.

Hoffmann, B.; Bahr, J.; Hixon, J.E. and Wagner, W.C. (1979): Observations concerning the functional status of the corpus luteum and the placenta around parturition in the cow. Anim. Reprod. Sci. 2: 253-266.

IYoffmann, B.; Goes de Pintho, T. and Schuler, G. (1997): Determination of free and conjugated oestrogens in peripheral blood plasma, feces and urine of cattle throughout pregnancy. Exp. Clin. Endcrinol. Diabetes. 105: 296-303.

Kaufmann, P. and Burton, G. (1994): Anatomy and genesis of the placenta. In: The physiology of reproduction, $2^{\text {nd }} \mathrm{Ed}$ (ed. Knobil E and Neill J D), Raven Press, Ltd, New York, pp 441-484.

Klisch, K.; Pfarrer, C.; Schuler, G.; Hofmann, B. and Leiser, R. (1999): Tripolar acytokinetic mitosis and formation of feto-maternal syncytia in the bovine placentome: different modes of the generation of multinuclear cells. Anat. Embryol. 200: 229-237.

Leiser, $R$. and Kaufmann, P. (1994): Placental structure: in a comparative aspect. Exp. Clin. Endocrinol. 102: 122-134.

Loriaux, D.L.; Ruder, H.J.; Knab, D.R. and Lipsett, M.B. (1972): Estrone sulphate, estrone, estradiol and estriol plasma level in human pregnancy. J. Clin. Endcrinol. Metab. 35: 887-891.

luft, J.H. (1961): Improvement in epoxy resin embedding methods. J. Biochem. Cytol. 9: 409-414.

Reimers, T.J.; Ullman, M.B. and Hansel, W. (1985): Progesterone and prostanoid Production by bovine binucleate trophoblast cells. Biol. Reprod. 33: 1227-1236.

Riberio, R.C.; Kushner, P.J. and Baxter, J.D. (1995): The nuclear hormone receptor gene superfamily. Ann. Rev. Med. 46: 443453.

Sauerwein, H.; Meyer, H.H.H. and Möstl, E. (1989): Low sensitivity to estrogens in bovine placenta at term. Zentralbl. Veterinaermed Reihe A. 36: 236-240.

Schuler, G.; Hartung, F. and Hoffmann, B. (1994): Investigation on the use of C-21-steroid as precursors for placental oestrogen synthesis in the cow. Exp. Clin. Endcrinol. 102: 122-134.

Schuler, G.; Wirth, C.; Klisch, K.; Pfarrer, C.; Leiser, R. and Hoffmann, B. (1999): immunolocalization of progesterone receptors in bovine placentomes throughout mid and late gestation and at parturition. Biol. Reprod. 61: 797-801. 
Schuler, G.; Wirth, C.; Teichmann, U.; Failing, K.; Leiser, R.; Thole, H. and Hoffmann, B. (2002): Occurrence of estrogen receptor $\alpha$ in bovine placentomes throughout mid and late gestation and at parturition. Biol. Reprod. 66: 976-982.

Skidmore, J.A.; Wooding, F.B.P. and Allen, W.R. (1996): Implantation and early placentation in the one-humped camel (Camelus dromedarius). Placenta 17: 253-262.

Thorburn, G.D. and Harding, R. (1994): Textbook of fetal physiology. Oxford University Press, Oxford, New York, Tokyo.

Tsumagari, S.; Kamata, J.; Takagi, K.; Tanemura, K.; Yosai, A. and Takeshi, M. (1993): Aromatase activity and oestrogen concentration in bovine cotyledons and caruncles during gestation and parturition. J. Reprod. Fert. 98: 631-636.

Wooding, F.B.P. (1982): The role of the binucleate cell in ruminant placental structure. J. Rprod. Fertil Suppl 31:31-39.

Wooding, F.B.P. (1992): The synepitheliochorial placenta of ruminants: binucleate cell fusion and hormone production. Placenta 13: 101-113.

Wooding, F.B.P. and Flint, A.P.F. (1994): Placentation. In Marshall's Physiology of Reproduction. $4^{\text {th }}$ ed. (ed. Lamming GE), Chapman and Hall, London, Vol. III, Part 1, pp. 233-460.

Wooding, F.B.P.; Morgan, G. and Adam, C.L. (1997): Structure and function in the ruminant synepitheliochorial placenta: Central role of the trophoblast binucleate cell in deer. Microsc. Res. Techn., 38: 88-99. 